DOI

\title{
ДИНАМКА ПОКАЗНИКІВ ЛІПІДНОЇ ПЕРОКСИДАЦІї ТА АНТИОКСИДАНТНОГО ЗАХИСТУ ТКАНИНИ ПЕЧІНКИ В РАННІЙ ПЕРІОД ПІСЛЯ НАНЕСЕННЯ ПОЛІТРАВМИ У ТВАРИН 3 ХРОНІЧНИМ ГЕПАТИТОМ
}

\section{ДВНЗ «Тернопільський державний медичний університет імені І. Я. Горбачевського МОз України»}

РЕЗЮМЕ. В умовах політравми в ранній період травматичної хвороби спостерігається інтенсифікація ліпідної пероксидації, яка проявляється збільшенням вмісту у тканині печінки ТБК-активних продуктів ПОЛ, порівняно із контрольною групою На тлі супутнього хронічного гепатиту і політравми показник істотно більший, ніж у групі тварин без хронічного гепатиту через 1 i 7 діб після нанесення травми, проте амплітуда його відхилень $\epsilon$ меншою, порівняно із тваринами без хронічного гепатиту. В умовах політравми у тканині печінки настає істотне збільшення активності СОД, зниження каталази та величини АПІ, які досягають максимальних порушень через 3 доби і згодом змінюються в бік норми, проте її не досягають. На тлі супутнього хронічного гепатиту і політравми вони змінюються аналогічно за вектором, проте з меншою амплітудою. Їх максимальне порушення настає через 1-3 доби й залишається на такому ж рівні до 7 доби.

КЛЮчОВІ СЛОВА: політравма, хронічний гепатит, печінка, ліпідна пероксидація, антиоксидантний захист

Вступ. Актуальною проблемою сьогодення став травматизм. Він входить у трійку провідних причин смертності поруч із серцево-судинними та онкологічними захворюваннями $[10,17]$. Основною причиною загибелі організму при тяжкій множинній і поєднаній травмі $є$ розвиток поліорганної недостатності [13]. В її патогенезі лежить системна гіпоксія, активація пероксидації ліпідів клітинних мембран, яка призводить до їх деструкції. Вихід лізосомальних ферментів замикає чергове патологічне «хибне» коло, посилюючи процеси запалення і системні реакції організму [7].

Одним з об'єктів системної відповіді організму на травму $\epsilon$ печінка. В численних публікаціях показано, що внаслідок тяжкої скелетної травми в цьому органі виникають виражені морфофункціональні порушення, знижується детоксикаційна функція гепатоцитів, що поглиблює перебіг травматичної хвороби $[4,9]$.

Одночасно в Україні відмічається збільшення захворюваності на гепатити різного походження. Тільки у 2011 році питома вага хронічного гепатиту в Україні в загальній структурі хронічних захворювань органів травлення становила 5 \%, показник поширеності - 944 на 100 тис. дорослого населення [15], що робить високою вірогідність виникнення політравми на тлі ураження печінки. Однак в доступній літературі не висвітлені особливості перебігу травматичної хвороби в умовах хронічного гепатиту, що спонукає до поглибленого вивчення патогенезу комбінації цих патологічних процесів.

Мета роботи - з'ясувати динамку показників ліпідної пероксидації та антиоксидантного захисту тканини печінки в ранній період після нанесення політравми у тварин з хронічним гепатитом.
Матеріали і методи дослідження. Експерименти виконані на 98 нелінійних білих щурах-самцях масою 180-200 г. У першій дослідній групі моделювали хронічний гепатит за методом Siegers C. P. et al. (1982) шляхом внутрішньоочеревинного введення 50 \% олійного розчину тетрахлорметану в дозі 0,2 мл·к $\Gamma^{-1}$ два рази на тиждень впродовж чотирьох тижнів із заміною питної води 5 \% розчином етанолу [16]. У другій дослідній групі замість розчину тетрахлорметану вводили фізіологічний розчин в еквівалентній дозі. Через 4 тижні тваринам обох дослідних груп моделювали політравму за методом Т. Я. Секели та А. А. Гудими (2008). Під тіопенталонатрієвим наркозом (40 мг·кг ${ }^{-1}$ ) в асептичних умовах у тварин викликали кровотечу зі стегнової вени (близько 20 \% об'єму циркулюючої крові), кров вводили у паранефральну клітковину з розрахунку 1 мл на 100 г маси тварини. Далі з оперативного доступу ламали стегно, рану зашивали [12]. Контрольні групи склали інтактні тварини та тварини із хронічним гепатитом.

Тварин, які вижили, виводили з експерименту в умовах знеболювання методом тотального кровопускання з серця через 1, 3 і 7 діб після нанесення травми. Видаляли печінку, в гомогенаті якої визначали вміст ТБК-активних продуктів ПОЛ [1], активність супероксиддисмутази (СОД) [14], каталази [11] та розраховували антиоксидантнопрооксидантний індекс (АПІ) за співвідношенням активності каталази до вмісту ТБК-активних продуктів ПОЛ [2].

Для оцінки вірогідності відмінностей між контрольними і дослідними групами проводили статистичний аналіз отриманих результатів із використанням програми STATISTICA 10.0 («StatSoft, Inc.", США). 
Огляди літератури, оригінальні дослідження, погляд на проблему

Результати й обговорення. Як видно з таблиці 1 , у групі тварин без хронічного гепатиту вміст у тканині печінки ТБК-активних продуктів ПОЛ в умовахмодельованоїполітравми був більшим, порівняно із контрольною групою: через 1 добу -у 2,52 раза $(p<0,05)$, через 3 доби - у 2,44 раза $(p<0,05)$, через 7 діб - у 2,13 раза $(p<0,05)$. В умовах хронічного гепатиту показник вже у контрольній групі виявився на 75,8 \% більшим, ніж в інтактних тварин $(p<0,05)$. На тлі політравми він зростав і у всі терміни перевищував рівень контрольної групи: відповідно на 17,9, $65,1$ і $66,4 \%$ ( $<<0,05)$. Як видно, ступінь приросту показника в цій групі був меншим, ніж у групі тварин без гепатиту, проте абсолютна величина через 1 добу виявилася статистично вірогідно меншою (на $24,8 \%, p<0,05$ ), через 3 доби вона між групами порівняння була неістотною ( $>>0,05)$, проте через 7 діб у групі тварин із хронічним гепатитом суттєво перевищувала - на 25,8 \% ( $<<0,05)$.

Аналіз динаміки вмісту ТБК-активних продуктів ПОЛ у дослідних групах показав, що у тварин без хронічного гепатиту показник досягав максимальної величини через 1 добу посттравматичного періоду й до 7 доби поступово знижувався, стаючи статистично вірогідно меншим, ніж у попередні терміни спостереження $(p<0,05)$. В умовах хронічного гепатиту показник, навпаки, збільшувався з 1 до 7 діб. В цих умовах він через 3 і 7 діб виявився статистично вірогідно більшим, ніж через 1 добу $(p<0,05)$.

Таблиця 1. Рівень ліпідної пероксидації та антиоксидантного захисту тканини печінки в динамці раннього періоду травматичної хвороби на тлі хронічного гепатиту $(\mathrm{M} \pm \mathrm{m})$

\begin{tabular}{|c|c|c|c|c|c|}
\hline \multirow{2}{*}{ Показник } & \multirow{2}{*}{ Дослідна група } & \multirow{2}{*}{$\begin{array}{c}\text { Контроль } \\
(n=6 / 7)\end{array}$} & \multicolumn{3}{|c|}{ Політравма } \\
\hline & & & 1 доба $(n=9 / 10)$ & 3 доба ( $n=8 / 9)$ & 7 доба (n=8/9) \\
\hline \multirow{2}{*}{$\begin{array}{l}\text { ТБК-активні } \\
\text { продукти ПОЛ, } \\
\text { мкмоль· } \Gamma^{1}\end{array}$} & без гепатиту & $3,23 \pm 0,16$ & $8,91 \pm 0,31 *$ & $8,62 \pm 0,31 *$ & $7,51 \pm 0,25^{* 1,3}$ \\
\hline & хронічний гепатит & $5,68 \pm 0,23$ & $6,70 \pm 0,24^{*}$ & $9,38 \pm 0,24 * 1$ & $9,45 \pm 0,32 * 1$ \\
\hline \multicolumn{2}{|l|}{. } & $<0,05$ & $<0,05$ & $>0,05$ & $<0,05$ \\
\hline \multirow{2}{*}{ СОД, ум.од. $\cdot$ к ${ }^{1}$} & без гепатиту & $0,074 \pm 0,004$ & $0,176 \pm 0,007^{*}$ & $0,195 \pm 0,010 *$ & $0,202 \pm 0,009 * 1$ \\
\hline & хронічний гепатит & $0,060 \pm 0,004$ & $0,093 \pm 0,007^{*}$ & $0,105 \pm 0,006^{*}$ & $0,091 \pm 0,006^{*}$ \\
\hline \multicolumn{2}{|r|}{$\mathrm{p}$} & $<0,05$ & $<0,05$ & $<0,05$ & $<0,05$ \\
\hline \multirow{3}{*}{$\begin{array}{l}\text { Каталаза, } \\
\text { мккат·кг }\end{array}$} & без гепатиту & $5,25 \pm 0,24$ & $4,13 \pm 0,15^{*}$ & $3,53 \pm 0,15 * 1$ & $4,53 \pm 0,20 * 3$ \\
\hline & хронічний гепатит & $4,15 \pm 0,16$ & $3,61 \pm 0,14^{*}$ & $3,52 \pm 0,14^{*}$ & $3,69 \pm 0,16$ \\
\hline & $\mathrm{p}$ & $<0,05$ & $<0,05$ & $>0,05$ & $<0,05$ \\
\hline \multirow{3}{*}{\begin{tabular}{|l|} 
АПІ, \\
ум. од. \\
\end{tabular}} & 6ез гепатиту & $1,50 \pm 0,09$ & $0,47 \pm 0,02^{*}$ & $0,42 \pm 0,03^{*}$ & $0,61 \pm 0,04 * 1,3$ \\
\hline & хронічний гепатит & $0,74 \pm 0,05$ & $0,54 \pm 0,03^{*}$ & $0,38 \pm 0,02 * 1$ & $0,39 \pm 0,01 * 1$ \\
\hline & $p$ & $<0,05$ & $>0,05$ & $>0,05$ & $<0,05$ \\
\hline
\end{tabular}

Примітки:

1. *- відмінності стосовно контрольної групи статистично вірогідні $(p<0,05)$;

2. p - вірогідність відмінностей між групами без гепатиту та із хронічним гепатитом;

3. 1,3 - показники стосовно 1 і 3 діб спостереження статистично вірогідні $(p<0,05)$

4. n-у чисельнику: кількість тварин у дослідній групі без гепатиту, у знаменнику: із хронічним гепатитом.

Активність СОД у тканині печінки під впливом політравми збільшувалася й через 1 добу перевищувала рівень контролю у 2,39 раза $(p<0,05)$, через 3 доби - у 2,63 раза $(p<0,05)$, через 3 доби 2,73 раза $(p<0,05)$. На тлі хронічного гепатиту вже у контрольній групі активність СОД у тканині печінки була нижчою, ніж у тварин без хронічного гепатиту (на $18,9 \%, p<0,05)$. Проте на тлі політравми величина досліджуваного показника теж зростала: відповідно на 55,0, 75,0 і 51,7 \%, що виявилося статистично значущим у порівнянні із контрольною групою $(p<0,05)$, проте суттєво меншим, ніж у групі без хронічного гепатиту: через 1 добу - на $47,2 \%(p<0,05)$, через 3 доби - на 46,2 \% ( $p<0,05)$, через 7 діб - на 55,0 \% ( $<<0,05)$.

Аналіз динаміки досліджуваного показника показав, що у тварин без гепатиту показник по- ступово зростав до 7 доби і в цей термін виявився істотно більшим, ніж через 1 добу $(p<0,05)$. В умовах хронічного гепатиту показник досягав максимальної величини через 1 добу й залишався на такому ж рівні до 7 доби $(p<0,05)$.

Активність каталази тканини печінки в умовах політравми знижувалася: через 1 добу - на $21,3 \%(p<0,05)$, через 3 доби - на 32,8 \% $(p<0,05)$, через 7 діб - на 13,7 \% $(p<0,05)$. На тлі хронічного гепатиту показник у контрольній групі виявився на 21,0 \% меншим, ніж у тварин без гепатиту $(p<0,05)$. В умовах політравми в цій групі через $1 \mathrm{i}$ 3 доби він теж був нижчим, ніж у контролі (відповідно на 13,0 і 15,2 \%, p<0,05). Через 7 діб показник знаходився на рівні контрольної групи (p>0,05).

Аналіз динаміки активності каталази тканини печінки показав, що у тварин без хронічного 
Огляди літератури, оригінальні дослідження, погляд на проблему

гепатиту вона досягала мінімальної величини через 3 доби, що було статистично вірогідно меншим, ніж через 1 добу $(p<0,05)$. Через 7 діб показник зростав і виявився істотно більшим, ніж через 3 доби $(p<0,05)$. В умовах хронічного гепатиту показник досягав мінімальної величини вже через 1 добу й залишався на такому ж рівні до 3 доби $(p>0,05)$ з наступною нормалізацією через 7 діб.

Величина АПІ під впливом модельованої політравми знижувалася й через 1 добу виявилася меншою, ніж у контрольній групі, на 68,7 \%, через 3 доби - на 72,0 \%, через 7 діб - на 59,3 \%, що було статистично вірогідним ( $<<0,05)$. В умовах хронічного гепатиту показник вже у контрольній групі був істотно меншим, ніж у групі без хронічного гепатиту (на 50,6 \%, p<0,05). На тлі політравми він теж знижувався: відповідно на 27,0, 48,6 i $47,3 \%(p<0,05)$. Порівнюючи дослідні групи між собою в динаміці посттравматичного періоду ми з'ясували, що через 1 і 3 доби відмінності величини АПІ між дослідними групами були неістотними ( $>0,05)$, проте через 7 діб у тварин із супутнім хронічним гепатитом показник виявився значно меншим (на 36,1\%, р<0,05).

Аналіз динаміки величини АПІ в посттравматичному періоді показав, що у тварин без супутнього хронічного гепатиту показник максимально знижувався через 1 і 3 доби і в подальшому зростав, стаючи істотно більшим, ніж у попередні терміни спостереження ( $<20,05)$. В цих умовах супутній хронічний гепатит зумовлював поступове зниження показника до 3 доби, що виявилося істотно меншим, ніж через 1 добу $(p<0,05)$. Через 7 діб він знаходився на рівні 3 доби $(p>0,05)$.

Таким чином, в умовах політравми в ранній період травматичної хвороби спостерігається інтенсифікація ліпідної пероксидації, яка проявляється збільшенням вмісту у тканині печінки ТБКактивних продуктів ПОЛ у порівнянні із контрольною групою, що відповідає сучасним уявленням про перебіг раннього періоду травматичної хвороби після механічної травми $[3,5]$. На тлі супутнього хронічного гепатиту величина цього показника вже в контрольній групі була більшою, ніж у тварин без хронічного гепатиту, що пов'язано із специфікою ураження печінки тетрахлорметаном і етанолом [6]. На тлі політравми в умовах хронічного гепатиту показник продовжує залишатися істотно більшим, ніж у групі тварин без хронічного гепатиту. Привертає увагу той факт, що амплітуда його відхилень у динаміці політравми є меншою, порівняно із тваринами без хронічного гепатиту. В умовах політравми показник до 3 доби збільшувався із наступним зниженням до 7, тоді як в умовах супутнього хронічного гепатиту показник теж досягав максимальної величини до 3 доби, проте продовжував залишатися на такому ж рівні до 7 доби.

В умовах політравми у тканині печінки настає істотне збільшення активності СОД, зниження каталази та величини АПІ, які досягають максимальних порушень через 3 доби і в подальшому змінюються в бік норми, проте її не досягають. Подібні результати отримано й у роботах інших авторів [8]. На тлі супутнього хронічного гепатиту досліджувані показники нижчі, ніж у тварин без хронічного гепатиту. В умовах політравми вони змінюються аналогічно за вектором, проте з меншою амплітудою. Їх максимальне порушення настає через 1-3 доби й залишається на такому ж рівні до 7 доби. В динаміці політравми на тлі супутнього хронічного гепатиту величини досліджуваних показників менші, ніж у тварин без хронічного гепатиту, що найхарактерніше для 7 доби спостереження.

Можна припустити, що в умовах супутнього хронічного гепатиту і політравми настає нашарування патогенних механізмів обох модельованих патологій, що зумовлює більші порушення процесів ліпідної пероксидації та антиоксидантного захисту в печінці. Разом з тим, на тлі хронічного гепатиту динаміка досліджуваних показників $\epsilon$ більш інертною, що, на наш погляд, вказує на нижчу реакційну здатність паренхіми ураженої печінки на вплив патогенних чинників травматичної хвороби. В цих умовах, очевидно, навіть незначні порушення показників ліпопероксидації та антиоксидантного захисту в динаміці політравми свідчать про наявність глибоких некробіотичних змін у гепатоцитах, проте можуть трактуватися як хибно позитивний результат, що слід враховувати у комплексній інтенсивній терапії травматичної хвороби.

Висновки. 1. В умовах політравми в ранній період травматичної хвороби спостерігається інтенсифікація ліпідної пероксидації, яка проявляється збільшенням вмісту у тканині печінки ТБКактивних продуктів ПОЛ. На тлі супутнього хронічного гепатиту і політравми показник істотно більший, ніж у групі тварин без хронічного гепатиту через 1 і 7 діб після нанесення травми, проте амплітуда його відхилень $\epsilon$ меншою, ніж у тварин без хронічного гепатиту.

2. В умовах політравми у тканині печінки настає істотне збільшення активності СОД, зниження каталази та величини АПІ, які досягають максимальних порушень через 3 доби і в подальшому змінюються в бік норми, проте її не досягають. На тлі супутнього хронічного гепатиту і політравми вони змінюються аналогічно за вектором, проте $з$ меншою амплітудою. Їх максимальне порушення 
Огляди літератури, оригінальні дослідження, погляд на проблему

настає через 1-3 доби й залишається на такому ж рівні до 7 доби.

Перспективи подальших досліджень. У перспективі передбачається дослідження ло- кального і системного впливу препаратів із гепатопротекторними властивостями у ранній період травматичної хвороби в умовах політравми та хронічного гепатиту.

\section{ЛІТЕРАТУРА}

1. Андреева Л. И. Модификация метода определения перекисей липидов в тесте с тиобарбитуровой кислотой / Л. И. Андреева, Л. А. Кожемякин, А. А. Кишкун // Лаб. дело. - 1988. - № 11. - С. 41-43.

2. Антиоксидантно-прооксидантний індекс сироватки крові щурів з експериментальним стоматитом і його корекція зубними еліксирами / А. П. Левицький, В. М. Почтар, О. А. Макаренко, Л. І. Гридіна // Одеський мед. журн. - 2006. - № 1. - С. 22-25.

3. Борис Р. М. Особливості пероксидного окиснення ліпідів у період гострої реакції на поєднану краніоскелетну травму/Р.М.Борис//Актуальные проблемытранспортной медицины. - 2013. - № 2 (32). - С. 149-153.

4. Волотовська Н. В. Роль гемічної гіпоксії в патогенезі порушень жовчоутворювальної і жовчовидільної функцій печінки на тлі скелетної травми в ранньому посттравматичному періоді / Н. В. Волотовська, А. А. Гудима // Здобутки клінічної і експериментальної медицини. -2011 . - № 2(15). - С. 31-33.

5. Волотовська Н. В. Динаміка показників вільнорадикального окислення і антиоксидантного захисту тканин печінки в умовах політравми / Н. В. Волотовська // Медична хімія. - 2011. - Т. 13, № 4(49). - С. 224.

6. Гудима А. А. Вплив лансопразолу, метронідазолу і кларитроміцину на функціональний стан печінки і його корекція тіотриазоліном в умовах хронічного експериментального гепатиту / А. А. Гудима, В. В. Підгірний // Запорізький медичний журнал.- 2007. - № 5. - С. 33-37.

7. Дзюба Д. А. Показатели активации апоптоза в течении политравмы тяжелой степени / Д. А. Дзюба, И. Р. Малыш, Л. В. Згржебловская //Український журнал екстремальної медицини імені Г. О. Можаєва. - 2008. Т. 9, № 1. - С. 53-58.

8. Козак Д. В. Динаміка показників антиоксидантного захисту у відповідь на політравму / Д. В. Козак // Шпитальна хірургія. - 2012. - № 3 (59). - С. 60-64.

9. Козак Д. В. Особливості функціонального стану печінки в динаміці раннього посттравматичного

періоду політравми / Д. В. Козак // Biomedical and Anthropology. - 2013. - № 20. - C. 97-99.

10. Актуальні питання організації і надання ургентної допомоги при торакоабдомінальній травмі / Я. Г. Колкін, І. В. Мухін, В. В. Хацко [та ін.] // Шпитальна хірургія. - 2004. - № 4. - С. 145-148.

11. Метод определения активности каталазы / М. А. Королюк, Л. И. Иванова, И. Г. Майорова, В. Е. Токарев // Лабораторное дело. - 1988. - № 1. - С. 16-19.

12. Пат. на корисну модель 30028 Україна МІЖ 2006 G 09 B 23/00. Спосіб моделювання політравми / Т. Я. Секела, А. А. Гудима (Україна) ; заявник і патентовласник Тернопільський мед. університет. - № U 200710471 ; заявл. 21.09.2007 ; опубл. 11.2.08; Бюл. № 3-4.

13. Селезнев С. А. Изменения функций внутренних органов при тяжелой механической травме / С. А. Селезнев, С. Ф. Багненко, Ю. Б. Шапот // Нарушения функции мозга и внутренних органов при сочетанной механической травме и терминальных состояниях : материалы к "круглому столу" / СПб. : НИИ скорой помощи им. И. И. Джанелидзе. - СПб., 2001. - 18 с.

14. Чевари С. Роль супероксиддисмутазы в окислительных процессах клетки и метод определения ее в биологических материалах [Текст] / С. Чевари, И. Чаба, Й. Сокей // Лаб. дело. - 1985. - № 11. - С. 678-681.

15. Щербина М. Б. Інновації в лікуванні хронічних медикаментозних та алкогольних гепатитів / М. Б. Щербина // Гастроентерологія. - 2012. - №29. C. $48-50$.

16. Effects of dithiocarb and (+) cyanidanol-3 on the $\mathrm{CCL}_{4}$ alcohol induced fibrosis of rat liver / C. P. Siegers, V. Voipel, G. Schel [et al.] // Connective Tissue Norn. and Fibrotis. Hum. Liver. Stuttgart. New-York. - 1982. - Vol. 3. P. 244-245.

17. Peden M. World report on road traffic injury prevention. / M. Peden, R. Scurfield, D. Sleet [et al.] // Geneva, Switzerland: World Health Organization; 2004. 


\section{DYNAMICS OF LIPID PEROXIDATION AND ANTIOXIDANT PROTECTION INDICATORS OF LIVER TISSUE IN THE EARLY PERIOD AFTER THE APPLICATION OF MULTIPLE INJURIES IN ANIMALS WITH CHRONIC HEPATITIS}

OR. V. Blyzniuk

SHEI «Ternopil State Medical University by I. Ya. Horbachevsky of MPH of Ukraine»

SUMMARY. In the context of polytrauma in the early period of traumatic disease is observed intensification of lipid peroxidation, which is manifested by an increase of content in the liver tissue of TBA-reactive products of lipid peroxidation compared to the control group. Against the background of concomitant chronic hepatitis and polytrauma indicator is much higher than in the group of animals without chronic hepatitis at 1 and 7 days after injury, but its amplitude deviations less than the animals without chronic hepatitis. In the context of polytrauma occurs in the liver tissue significantly increase SOD activity, decrease - catalase and magnitude API, which reach their maximal after 3 days of violations and further changed towards the norm, but it does not reach. Against the background of concomitant chronic hepatitis and polytrauma they change analogous to the vector, but with a smaller amplitude. Their maximum violation occurs after 1-3 days and remained at the same level up to 7 days.

KEY WORDS: polytrauma, chronic hepatitis, liver, lipid peroxidation, antioxidant protection. 